\title{
(ii) $\mathrm{sec}$ \\ Instituto de Investigaciones Socio Económicas
}

Documento de Trabajo No. 01/06

Febrero 2006

\section{Market and Inequality Revisited}

por:

Alejandro F. Mercado

Tirza J. Aguilar 


\title{
Market and Inequality Revisited
}

\author{
Alejandro F. Mercado* \\ Tirza J. Aguilar
}

\begin{abstract}
The great controversy regarding the results of the application of market-oriented policies on the population's conditions of life, especially about the inequality in the distribution of income, has constituted the concern that has given origin to this paper.

With the objective to test the hypothesis that a free market structure promotes a better income distribution, we have carried out several quantifications of inequality indices in the different structures of the labor market in Bolivia; also, a microsimulation model has been applied, to see whether change toward a market-oriented structure can improve the distribution of income and, lastly, we have carried out an exercise to link income inequality with social mobility.
\end{abstract}

The reached results, although they are not the sufficiently strong to validate the hypothesis, are sufficiently clear to show us that the free market policies do not act in a negative way on the income distribution.

\section{Resumen}

La gran controversia respecto a los resultados de la aplicación de políticas orientadas al mercado sobre las condiciones de vida de la población, en especial sobre la desigualdad en la distribución del ingreso, ha constituido la preocupación que ha dado origen a este trabajo.

Con el objetivo de testear la hipótesis de que una estructura de libre mercado promueve una mejor distribución del ingreso, hemos realizado varias cuantificaciones de índices de desigualdad en las distintas estructuras del mercado laboral en Bolivia; asimismo, se ha aplicado un modelo de microsimulación, para ver en qué medida un cambio hacia políticas orientadas al mercado pueden mejorar la distribución del ingreso y, por último, se ha realizado un ejercicio para vincular la desigualdad del ingreso con la movilidad social.

Los resultados alcanzados si bien no son lo suficientemente fuertes para validar la hipótesis, son lo suficientemente claros para mostrarnos que las políticas de libre mercado no actúan de manera negativa sobre la distribución del ingreso.

* Alejandro F. Mercado and Tirza J. Aguilar are Director and Senior Researcher of IISEC, respectively.

- The authors would like to thank Jorge Leitón for many valuable comments and suggestions. The very constructive comments received from Miguel Fernández and Gustavo Canavire are highly appreciated, as well as the help we received from Javier A. Ibiett. 


\section{Introduction}

One of the more controversial elements in social analysis is how the market logic can deteriorate intra-group solidarity relationships. In our perception, that hypothesis is not correct. To the contrary, we think that the closer the activities are to the logic of the market, the more competitive processes will diminish the differences among individuals, especially in what corresponds to the income distribution.

Based on that assumption, in September 2005, we elaborated a draft paper: "Mercado y Desigualdad" (Working Paper No. 09/05-IISEC, UCB). The valuable comments of our colleagues of the university prompted us to continue working in this issue, resulting in the present paper.

Sections 2 and 3 of this paper review the theoretical framework on the economic rationality and the economic structure of Bolivia. In section 4 we decide to maintain a brief presentation of inequality indicators, especially with pedagogic objectives for our students' use. The fifth section, which referred to the inequality in the labor market of Bolivia, was reworked, incorporating the comments that we received, especially in what corresponds to the processing of the information contained in the MECOVI 2000. The sixth section introduces a new test of inequality, developed by Bourguignon, Ferreira and Leite. In section 7, we include an exercise to analyze the links between income distribution inequalities and social mobility. Lastly, we present the conclusions.

It is necessary to highlight that this paper is only a second approach to understanding the problem, and we think that the results obtained do not lead us to definitive conclusions; to the contrary, they open new alternatives for further investigations.

\section{A Note about Economic Rationality}

It is possible to define a human being like an animal with rational expectations or, precisely, we can distinguish a human being from other living creatures because they have three basic axiomatic necessities: "to be", "to have" and "to do." According to Hegel, the first category of his dialectical system is "to be", that is, the existence. Only if we take for granted the "to be" axiomatic necessities then we can define in the dialectical system, a "not to be" (Findlay, 1969). In human terms "to be" means identity and recognition. In other words, the history of mankind has been, "it is, and it will continue being", a constant fight for recognition. Power, wealth or merit, are only goods to satisfy the need to be recognized.

The need "to have" it is a natural requirement of appropriation, through the use of our work force, of natural resources for the human enjoyment. Although some theoretical approaches have tried to build a paradigm based on common or collective property, all these have failed because consumption has an individual character. No matter how much a group of people meets around a common table and share its goods, utility or satisfaction comes from consumption. The capacity to organize around this common table requires, a priori, the existence of private and individual property rights. Regardless of the need "to have", the concept that one person knows the value of goods is very important. Several theories failed because they value goods based on the work approach, when, in fact, value is determined by individuals.

The need "to do" shows us a reference to the positive and the negative freedom, that is, the individual requires acting in a system where her rights are not hindered by the desires of other human beings and, at the same time, in a self-determined capacity (Berlin, 1958). 
Before discussing the economic rationality, it is necessary to complete this trilogy of: "to be", "to have" and "to do", with a new axiomatic necessity. We refer to the necessity of trust, defined in the sense of Fukuyama (1996) as capital stock.

In the context of the exposed needs, the economic rationality is not another thing that makes an economic agent choose among a group of opportunities that he/she faces. People always choose the basket which dominates the other. This helps us to clarify the following components of this definition: rationality, election, group of opportunities and dominant alternative.

As Phelps (1986) clearly exemplifies, when a molecule collides against another object, it changes his trajectory. It is not possible to say that this change has been favorable or unfavorable, because the molecules do not want to arrive anywhere. On the contrary, human beings always make or say something with the purpose of reaching some objective, for which their decisions are rational in the sense that they support the attainment of their objectives. Election presupposes freedom, in the sense that it shows the capacity to opt for an alternative while rejecting the other ones. According to Sen (1988), the group of opportunities is known as capacities, those that represent the diverse combinations of operations that a person can reach, linked to the freedom of an individual to choose a type of life or another. The dominant alternative makes reference to the election of that opportunity by offering a bigger quantity of goods that the other ones.

Is this concept of rationality applicable to any group of people? The logic seems to behave as above, and, evidently, it is possible to apply this behavior as a reference model to investigate the behavior of the human being in its search to satisfy its needs at the highest possible level. Based on a cultural relativism, the critics of economic rationality only build models created in paper, but that they do not have any correspondence with reality (Mercado, 1997).

\section{Segmentation of the Economic Structure in Bolivia}

The heterogeneity that characterizes the labor market in Bolivia has generated a wide academic discussion from the decade of the 80's to the present, and it has produced a vast collection of literature. During the 80's, dependence theory predominated, and the search explained the labor phenomena base as an excess of the labor supply.

Within this context, the informal sector constituted itself as the paradigm for explaining labor market heterogeneity. It is necessary to highlight that the informal sector was not able to develop a group of solid categories that could allow us to give a correct exegesis of what was happening in the interaction between the goods and services market and the labor market.

The project "Work organization and distribution of income in Bolivia”, carried out by the Ministry of Planning in 1979, opened a new analytic perspective. Two research papers were derived from this project, and those created a conceptual approach that reflected, in a better way, the complexity of the labor market in Bolivia. Donoso (1980), tell us that in Bolivia, labor relationships do not correspond to purchases and sales of labor force. Donoso (1980), in order to prove her hypothesis, she carried out a survey to conclude that commercial capital relied greatly on independent agents for the distribution of its products. These independent distributors belong to a necessity of subsistence, but they also satisfy the necessity of distribution of the commercial capital, for which it is possible to consider them as the long arms of the commercial capital. This analytic proposal shows us that the frontiers of the labor market are very diffuse, and today they probably have more relevance than in the 
decade of the eighties. This phenomenon is not only present within commercial activities; productive capital includes this kind of practice as well.

Fernández (1983), constituted the theoretical framework of the discoveries of the work relationships in the different sectors of goods and suppliers of services in Bolivia. This investigation tells us that to study the structure and the operation of the labor market, it is necessary to start analyzing the iterative process of wealth creation that forms the relationship among the agents of the productive unit.

Fernández establishes a categorized structure of the labor market relationships, and later investigations consider this structure as instruments of segmentation of the labor market. In contrast to other categories developed in later studies, we have only taken into our analysis capitalist, semi-capitalists and family relationships.

Capitalist relationships are those that characterize the sector whose production is typically capitalist, based on waged manpower. There exists a real division of the work between the capital owners and the workers, which is also reflected in a bigger division of the work. In this environment, we can suppose that waged manpower corresponds to the productivity of the workers. In this sector, the workers have more capacity to organize in unions and, therefore, they have more capacity to push for the fulfillment of labor legislation. For our paper, we assume that this labor market segment is the nearest approximation of the market rules.

Semi-capitalist relationships correspond to those that are in the process of wealth creation, through which the capital owner is directly integrated with the work process. In other words, contrary to the capitalist units and the semi-capitalist units, the owner works together with the laborers, and there is no clear division of the work. In this segment of the labor market, the wage earners do not have union organizations to push for their labor rights; rather they are associated with organizations that include the capital owners. In sum, this segment of the labor market is an intermediate state between family organization and capitalist units, but this does not mean that they are a step toward the formation of capitalist units.

The family units are those in which the members of the labor force are also members of the family. One can attempt the hypothesis that these units respond to the survival strategies of the families. In this case, all the workers are members of the family, and production is also a family property. This segment of the labor market is far away from the market rules, and it does not fit the capitalist logic.

Following Fernández (1983), it is necessary to highlight that capitalist relationships are not presented in a pure form, which is, this form, through the articulation mechanisms, is presented among the different forms of organizing production. The articulation unit is generally linked to the market rules.

In the same analytic logic, the work of Laserna (2004) seeks to find the relationship among the forms of organizing production in Bolivia. However, contrary to Fernández, he does not explain the heterogeneity of the Bolivian economic structure starting with the relationships that characterize labor market relationships. Moreover Laserna identifies different economic structures based on their form of exchange and consumption of goods and services. Following this assumption, he classifies the market into three structures: the natural base economy, the mercantile economy and the family economy.

The structure of natural base is organized starting with access to the basic natural resources, such as earth and water. Their presence would be fundamental in a rural economy with strong community characteristics. The production decisions do not correspond to the 
market rationality and do not respond to the logic of maximizing benefits. The mercantile economy is formed by units organized to compete in markets, and they rest in a capitalist organization. The family economy is a symbiosis of the characteristics of both previous structures. They act in the market in the moment of selling their products, but in the creation of wealth, they take the form of family organizations.

As we can observe, Fernández' pioneer research and the recent work of Laserna are complementary, and they require a conceptual discussion and some additional empirical studies to build a combined structure organized by category. We believe that this would be an important advance in the search for an understanding of the heterogeneity that characterizes the Bolivian structure.

With the objective of building a wider explanatory model, it also would be important to incorporate the sociological point of view of the phenomenon. In that sense, Toranzo (1982, 1993), opened the vein to investigate the rationality and the reproductive logic of the economic agents that form the unit of articulation in the economic process. The concept of "burguesía chola" (chola bourgeoisie) does not imply only an ethnic characterization. It is a concept that allows us to build a different dialogue about the behavior of the commercial and productive capital. This approach, when it is combined with a multiethnic vision, can give us a new analytic framework to understand the complexity of our economic and social structure. These elements exceed the objective of this paper. However, we consider that they should be reviewed in future investigations.

\section{Measuring Inequality}

The basic element in all inequality measurement systems is the comparison between real or observed distribution and a foreseen or normative distribution. In the specific case of income (or wealth) inequality, the normative distribution is based on the democratic conception of justice, regarding the enjoyment of an arithmetic equality, that is, a distribution where the proportionality is equal to one.

The accumulative distributions rank individuals according their advantage ratios, allowing a figure comparison, as in the case of the Lorenz curve. With the objective of carrying out more precise estimates of inequality, diverse indicators have been created, each one with different grades of complexity and biases. Among the simplest indicators, we can mention: i) the Coefficient of Variation (standard deviation of the incomes divided by the arithmetic mean); ii) the Logarithmic Variation (standard deviation of theincome logarithms); and iii) the Gini coefficient and the Theil index are the most common inequality numerical indicators. Moreover, we can find other more complex inequality indicators like the Atkinson coefficient, the Rawls index among others.

The inequality indicators that are used in this paper are: the Lorenz curve, Gini coefficient, Kakwani index, Theil index and Atkinson coefficient. In the following text, we present a brief presentation of them. ${ }^{1}$

The Lorenz Curve represents the distribution of income, relating the population's cumulative percentages with the cumulative percentages of income. "Area A" in Figure 1 is known as the concentration area. The bigger area A is resultant of the "real" distribution compared with the "equality" distribution, the more concentrated income will be.

\footnotetext{
1 A detailed explanation of the main indicators of inequality can be found in Contreras, 1998.
} 
Figure 1:

Lorenz Curve

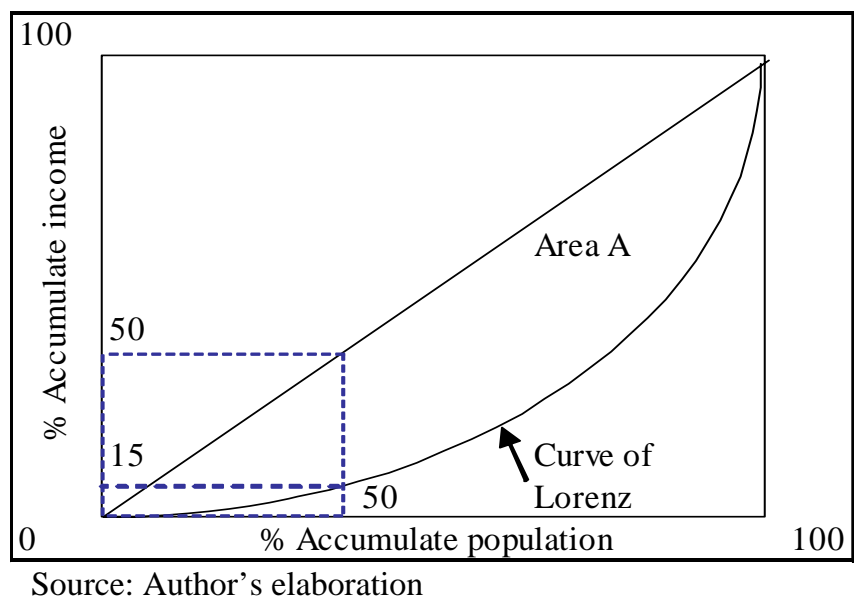

The Gini coefficient varies between zero and one. Zero is the ideal situation in which all the individuals or households have the same income, and one represents the value when incomes are concentrated on few individuals or households. The Gini coefficient is a value derived from the existent difference among each one of the deciles with regard to its deviation of the equitable norm, nomralized with regard to the population's size. It shows us the grade of inequality that exists in the distribution of income.

$$
G=\left|1-\sum_{k=0}^{k=n-1}\left(X_{k+1}-X_{k}\right)\left(Y_{K+1}+Y_{K}\right)\right|
$$

Where:

$$
\begin{aligned}
& \text { X: Population's cumulative proportion } \\
& \text { Y: Cumulative proportion of the incomes }
\end{aligned}
$$

The Kakwani Index. When we refer to income, the Kakwani coefficient of concentration is equivalent to the Gini coefficient, taking values between 0 and 1 . The closer to zero the coefficient is, the better the distribution of income will be; when the coefficient is closer to 1 , there will be a bigger inequality. The Kakwani index is obtained from the behavior of the Lorenz curve, but, contrary to these, the concentration coefficient can found in the area above or below the diagonal of perfect equality. Equation 2 shows the mathematic form of this coefficient:

$$
K=\frac{2}{n}\left(\frac{\sum_{i=1}^{n} x_{i} i}{\sum_{i=1}^{n} x_{i}}\right)-1-\frac{1}{n}
$$

Where:

$$
\begin{aligned}
& \mathrm{n} \text { : Number of observation classes } \\
& \mathrm{x} \text { : Income of each class }
\end{aligned}
$$


The Theil Index has the particularity of being divisible into two elements: a component of inequality between groups and an intra-group component. The Theil index varies between 0 (perfect equality) and $\mathrm{Ln}(\mathrm{N})$ (perfect inequality).

It can break down into " $n$ " hierarchical levels because it has the property of a mathematical fractal, that is, it replies in itself. The individuals can be divided into " $n$ " groups while each group is mutually exclusive. Therefore, the advantage of this statistical index is its flexibility and capacity to rank groups.

$$
\begin{aligned}
& I T \cong \sum_{g i=1}^{k} \frac{Y_{g}}{Y} \log \left(\frac{Y_{g} / Y}{n_{g / N}}\right) \\
& I T \cong I T E+I T D \\
& I T \cong \sum_{g i=1}^{k} \frac{Y_{g}}{Y}\left(\frac{Y_{g} / Y}{n_{g} / N}\right)+\left(\frac{Y_{g}}{Y}\right) \cdot \sum_{p=1}^{n_{g}} \frac{y_{g p}}{Y_{g}} \log \left(\frac{y_{g p} / Y_{g}}{1 / n_{g}}\right) \\
& \underbrace{}_{\text {ITE }} \underbrace{}_{\text {MD }}
\end{aligned}
$$

The Atkinson Coefficient The Atkinson coefficient allows us to introduce subjective values in the process of measuring income inequality. These yardsticks are captured by the coefficient $\varepsilon$. If $\varepsilon=0$, it means that the society is indifferent to inequality; whereas if $\varepsilon=1$, it would indicate the society only worries about inequality.

For their derivation, it leaves a concrete well-being function. The Atkinson coefficient of equality is defined as the income distributed in an equality path and the average income of the economy.

$$
A=1-\left[\left(\sum_{i=1}^{R} \frac{\mu_{i}}{\mu_{t}}\right)^{1-\varepsilon} f_{i}\right]^{\frac{1}{1-\varepsilon}}
$$

Where:

$$
\begin{aligned}
& \mu_{\mathrm{i}} \text { : Average income of the class } \\
& \mu_{\mathrm{t}} \text { : Average income of the whole population } \\
& \mathrm{f}_{\mathrm{i}}: \text { Population's percentage that is in the worst class } \\
& \mathrm{R}: \text { Total Number of classes } \\
& \varepsilon: \text { Coefficient of aversion }
\end{aligned}
$$

This index shows us that if we reduce the income levels by a specific quantity, at a maximum, it can maintain the same levels of well-being in the population. When the index is closer to one, the society comes closer to a perfect inequality. If it is closer to zero, we are close to an equal distribution. 


\section{Market and Inequality in Bolivia}

In this section, we used the database of MECOVI $2000^{2}$ for the capital cities and the city of El Alto, carrying out the following refinement: people who work in the government sector have been eliminated because we consider that high differences in wages respond to external factors that would alter our results. Likewise, family workers without remuneration and workers within cooperatives ${ }^{3}$ have been eliminated because the observations were very few and we could not identify clearly whether they were wage-earners or not.

In the following Figures (Figure 2 and Figure 3), we have wage and income distributions for the "Market" and the "Non-Market", respectively; where the "Market" corresponds to workers that carry out their labor activity based on wage relations, and the "Non-market" represents workers whose labor relationships do not correspond to wages (self-employed workers). In both cases, for the presented figures, we do not include incomes greater than Bs. 4.000 monthly because their statistical representation is small. As can be observed, the concentration of workers in lower income levels is greater for the case of the "Non-market" than for the case of the "Market". The highest frequencies within selfemployed workers are in the three lower classes. Fifty-six percent of these workers have smaller incomes than Bs. 601 while in the case of waged workers only 29 percent of them have a smaller income than Bs. 601 monthly.

It can also be observed that in the superior classes, that is to say, incomes greater than Bs. 601, the waged workers are above self-employed workers. This first approach shows us that workers in the "Market" have higher incomes than those who work in the "Nonmarket". This element would explain, partly, the pressure of workers to search for waged activities, especially when we study the behavior of the household heads.

Figure 2:

Income Distribution for the "Market"

(Percentage - 2000)

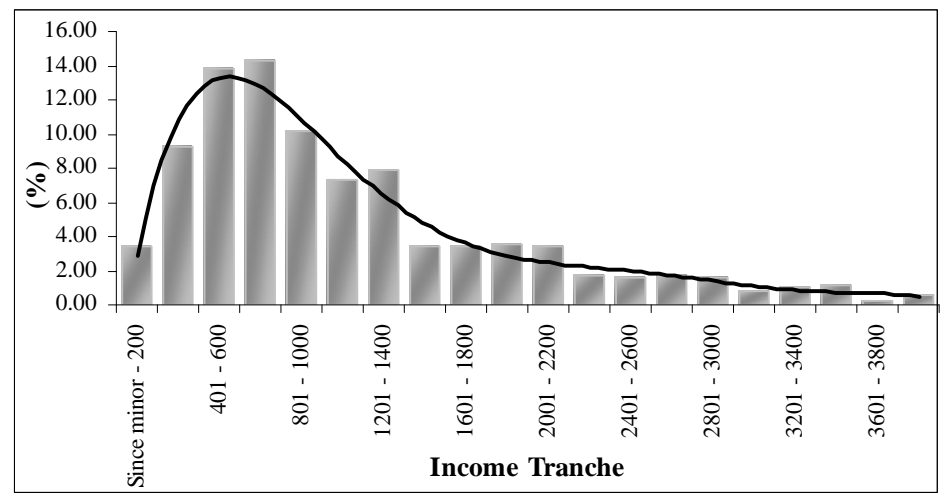

Source: Author’s elaboration based on MECOVI 2000

2 Encuesta de Mejoramiento de condiciones de Vida - 2000. The objective of this survey is to generate appropriate information on the conditions of the population's life.

3 A cooperative is a group of people with some economic and physical necessities in common that they unite with the purpose of lending service as a means to the community that surrounds them. 
Figure 3:

Income Distribution for the "Non Market"

(Percentage - 2000)

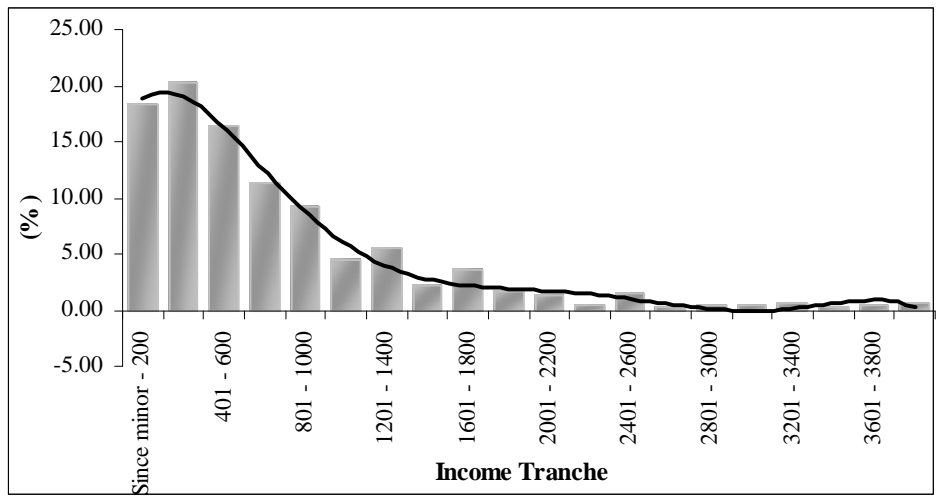

Source: Author’s elaboration based on MECOVI 2000

Before explaining the results obtained for the income distribution inequality in the "Market" and "Non-market" sectors and comparing them in order to assess in which sector the income distribution inequality is bigger, it is necessary to note that a direct observation would be misleading, as long as income differences explained by productivity cannot be taken as an indicator of inequality.

Therefore, the Mincer regression would allow us to find more precise results. The regression includes years of education, age of the workers and a gender dummy variable. The dependent variable is the logarithm of household income, according to the main household activity, and the independent variables are: age in years (YEARS), age in years squared (YEARS2), years of education $($ EDUCT), and gender dummy (Male $=1$, Female $=0$ ). All the variables are significant, and they present the expected signs. In addition, the regression fits well (Table 1).

Table 1:

Mincer Income Regression

(2000)

\begin{tabular}{|l|r|}
\hline Number of observations & $2,033.00$ \\
\hline F( 10, 1056) & 154.49 \\
\hline Prob $>$ F & 0.00 \\
R-squared & 0.23 \\
Adh R-squared & 0.23 \\
Root MSE & 0.97 \\
\hline
\end{tabular}

\begin{tabular}{|l|r|r|r|r|r|r|}
\hline Logarithm of Income & Coefficients & $\begin{array}{r}\text { Standard } \\
\text { Error }\end{array}$ & t-Statistic & P $>|\mathbf{t}|$ & \multicolumn{2}{|c|}{$\begin{array}{c}\text { 95\% Interval } \\
\text { of trust }\end{array}$} \\
\hline Age & 0.07 & 0.01 & 9.89 & 0.00 & 0.06 & 0.09 \\
Age-squared & $(0.00)$ & 0.00 & $(7.95)$ & 0.00 & $(0.00)$ & $(0.00)$ \\
Years of study & 0.09 & 0.00 & 18.21 & 0.00 & 0.08 & 0.10 \\
Gender & 0.39 & 0.04 & 8.79 & 0.00 & 0.30 & 0.48 \\
Constant & 3.85 & 0.15 & 24.87 & 0.00 & 3.54 & 4.15 \\
\hline
\end{tabular}

Source: Author's elaboration based on MECOVI 2000 
All the observed data were normalized with a base in this regression, so that the subsequently presented analysis of inequality is corrected by these variables.

Figure 4 shows a first approach to the comparative distribution of income between "Market" and "Non-market". We can observe clearly that the income distribution in waged activities is less unequal than in the non-waged activities. In other words, the more closely labor activities are to the market, the more equal income distributions are within this group. From another point of view, the closer the labor activities are to self-employed activities, the higher inequality among them is.

Figure 4:

\section{Comparative Lorenz Curves}

(Market and Non-Market - 2000)

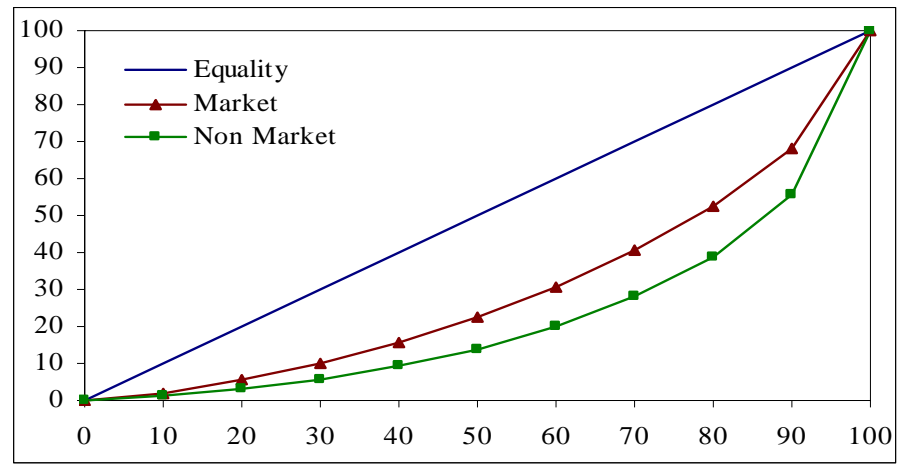

Source: Author’s elaboration based on MECOVI 2000

In the following figures (Figure 5 and Figure 6) the Lorenz curves are plotted for the "Market" and the "Non-market" sectors classified by gender. As can clearly be observed in Figure 5, the curves are very close, showing us the difference in inequality for the workers (male and female) who work in the "Market" is small. On the other hand, in the case of the activities within the "Non-Market", inequality is bigger, even more for the women subset (Figure 6).

Figure 5:

Lorenz Curves for the “Market” by Gender

(2000)

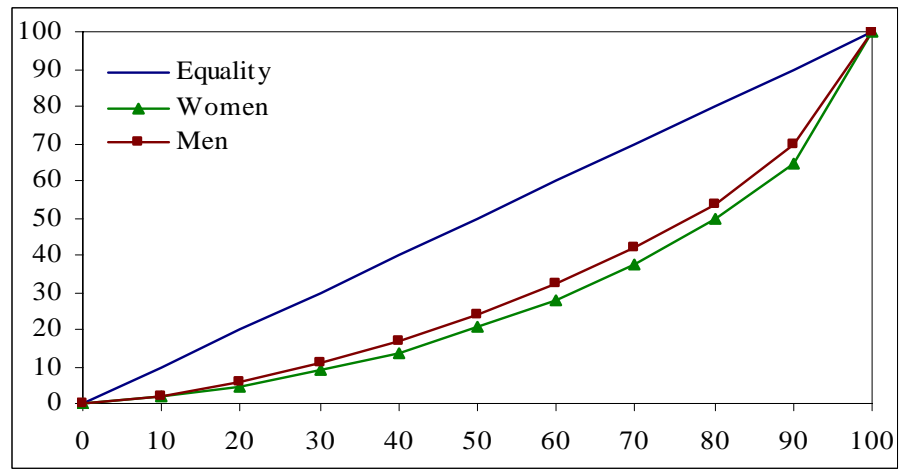

Source: Author’s elaboration based on MECOVI 2000 
Figure 6:

Lorenz Curves for the “Non-market” by Gender

(2000)

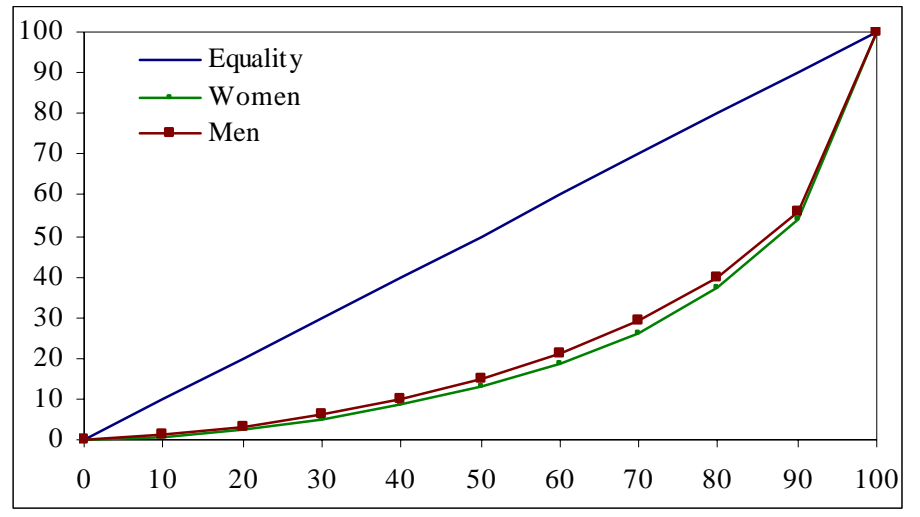

Source: Author's elaboration based on MECOVI 2000

In order to quantify the income inequality between the "Market" and the "Nonmarket" sectors, we have calculated the Gini coefficient, the results of which appear in the Table 2. It is observed that the inequality in the income distribution is higher within the "Non-Market" sector, that is, inequality is higher in labor activities where people are selfemployed rather then activities subject to wage conditions. These results corroborate what we have observed in the Lorenz curves. In the same way, inequality by gender is higher in the women intra-group in comparison with the men intra-group.

Table 2:

“Market” and “Non-Market” Gini Coefficient

\begin{tabular}{|l|l|}
\hline \multicolumn{2}{|c|}{ Gini's Coefficient } \\
\hline Total & $\mathbf{0 . 5 5 0}$ \\
Women & 0.577 \\
Men & 0.528 \\
\hline Market & $\mathbf{0 . 4 1 7}$ \\
Women & 0.459 \\
Men & 0.398 \\
\hline Non-Market & $\mathbf{0 . 5 7 0}$ \\
Women & 0.585 \\
Men & 0.555 \\
\hline
\end{tabular}

Source: Author’s elaboration based on MECOVI 2000

Following the Gini coefficient, the Theil index has been calculated. As shown in Table 3, it is evident that income inequality is higher in the labor activities outside the logic of the market as well as that the inequality is higher for the women in the "Non-Market" that in the "Market."

In the same way, the Kakwani index has been used (Table 4), and the results are similar to the previous one. That is, the inequality in the income distribution is higher in the sector that is furthest from the market rules.

The next step has been to investigate the inequality of income distribution at a more disaggregated level. For that we have taken workers in function to their location in what we denominate "Sectors of the labor market." The Lorenz curves in Figure 7 show us that the 
inequality in the distribution of income among workers who work in the capitalist sector is smaller than the inequality that is presented in the incomes of the workers who are in the semi-capitalist and in the family sector as well. It is necessary to highlight that the difference in the degree of inequality among the capitalist and the semi-capitalist sector is small.

Table 3:

“Market” and “Non-Market” Theil Index

\begin{tabular}{|l|c|}
\hline \multicolumn{2}{|c|}{ Theil's Index } \\
\hline Total & $\mathbf{0 . 6 2 6}$ \\
Women & 0.669 \\
Men & 0.598 \\
\hline Market & $\mathbf{0 . 3 4 3}$ \\
Women & 0.453 \\
Men & 0.295 \\
\hline Non-Market & $\mathbf{0 . 6 4 2}$ \\
Women & 0.665 \\
Men & 0.619 \\
\hline
\end{tabular}

Source: Author's elaboration based on MECOVI 2000

Table 4:

“Market” and “Non-Market” Kakwani Index

\begin{tabular}{|l|l|}
\hline \multicolumn{2}{|c|}{ Kakwani's Index } \\
\hline Total & $\mathbf{0 . 2 5 2}$ \\
Women & 0.275 \\
Men & 0.234 \\
\hline Market & $\mathbf{0 . 1 5 1}$ \\
Women & 0.182 \\
Men & 0.138 \\
\hline Non-Market & $\mathbf{0 . 2 6 8}$ \\
Women & 0.281 \\
Men & 0.255 \\
\hline
\end{tabular}

Source: Author’s elaboration based on MECOVI 2000

In Table 5, the results from the Gini coefficient analysis are presented by sector within the labor market and by gender. The income distribution worsens when we move away from the market labor conditions.

Figure 7:

Lorenz Curves for “Sector of Labor Market”

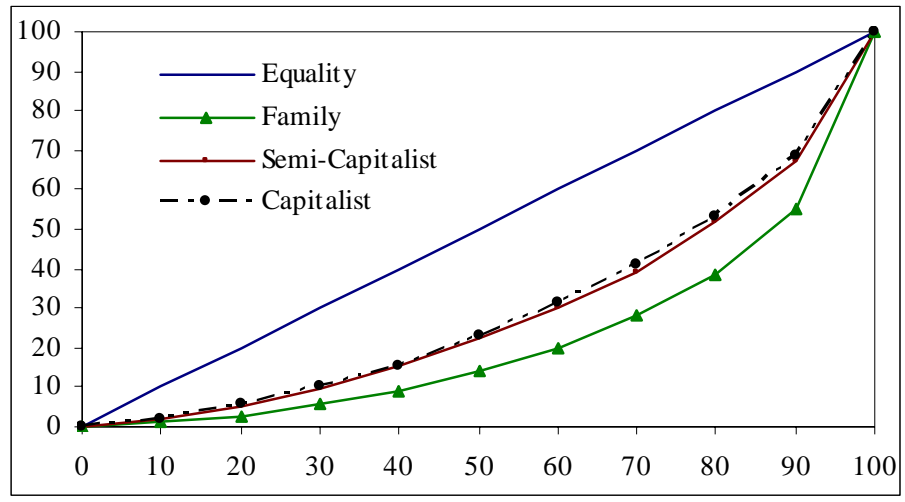

Source: Author's elaboration based on MECOVI 2000 
Table 5:

Gini Coefficient by Market Sector and Gender

\begin{tabular}{|l|l|}
\hline \multicolumn{2}{|c|}{ Gini's Coefficient } \\
\hline Family & $\mathbf{0 . 5 6 7}$ \\
Women & 0.582 \\
Men & 0.552 \\
\hline Semi-Capitalist & $\mathbf{0 . 4 3 0}$ \\
Women & 0.468 \\
Men & 0.416 \\
\hline Capitalist & $\mathbf{0 . 4 1 0}$ \\
Women & 0.454 \\
Men & 0.388 \\
\hline
\end{tabular}

Source: Author's elaboration based on MECOVI 2000

Lastly, to confirm the previous results, in Table 6 and Table 7 the Theil and Kakwani index are presented by market sector. These results prove the hypothesis, that is, the further labor activities are from the logic of the market, greater the inequality in the income will be.

Table 6:

Theil Index Market Sector

\begin{tabular}{|l|r|}
\hline \multicolumn{2}{|c|}{ Theil's Index } \\
\hline Family & $\mathbf{0 . 6 3 5}$ \\
Women & 0.656 \\
Men & 0.614 \\
\hline Semi-Capitalist & $\mathbf{0 . 3 8 2}$ \\
Women & 0.4540 \\
Men & 0.330 \\
\hline Capitalist & $\mathbf{0 . 3 1 1}$ \\
Women & 0.402 \\
Men & 0.267 \\
\hline
\end{tabular}

Source: Author's elaboration based on MECOVI 2000

Table 7:

Kakwani Index by Market Sector

\begin{tabular}{|l|l|}
\hline \multicolumn{2}{|c|}{ Kakwani's Index } \\
\hline Family & $\mathbf{0 . 2 6 5}$ \\
Women & 0.278 \\
Men & 0.253 \\
\hline Semi-Capitalist & $\mathbf{0 . 1 6 0}$ \\
Women & 0.193 \\
Men & 0.150 \\
\hline Capitalist & $\mathbf{0 . 1 4 6}$ \\
Women & 0.177 \\
Men & 0.132 \\
\hline
\end{tabular}

Source: Authors elaboration based on MECOVI 2000

\section{The Bourguignon Model}

The pattern developed by Bourguignon, Ferreira and Leite (2002) is a model of stages of micro simulations that expands the method of income decomposition proposed by OaxacaBlinder (1973), because it allows some variables of the income equation to be determined in a prior process that is also valued by the groups of study in a separate way. A distribution of 
the characteristics is simulated and substituted for the mean values of the observed characteristics.

A brief description is summarized in the following steps. First, it is necessary to divide the sample in two study groups. For the current study between market and non-market sectors, the non-market income is simulated under the supposition that it is the market.

Second, the pertinent estimated equations are:

$$
\begin{aligned}
& X=\alpha+\beta_{1} X_{1}+\beta_{2} X_{2}+\beta_{3} X_{3}+\varepsilon_{1} \\
& Y=\alpha+\beta_{1} Y_{1}+\beta_{2} Y_{2}+\beta_{3} Y_{3}+\varepsilon_{1}
\end{aligned}
$$

Where:

$$
\begin{aligned}
& \mathrm{X}, \mathrm{Y}: \quad \text { Education level } \\
& \mathrm{X}_{1}, \mathrm{Y}_{1}: \text { Age } \\
& \mathrm{X}_{2}, \mathrm{Y}_{2}: \text { Level of the mother's education } \\
& \mathrm{X}_{3}, \mathrm{Y}_{3}: \text { Region }
\end{aligned}
$$

The technique to estimate the equation is a polynomial logit for the "market" group. The coefficients estimated in the first equation are substituted in a similar equation for the “non-market” group (equation 1').

The third step consists of carrying out a polynomial logit model for the market. In the case of the simulated equation for the non-market, we will only include the women, then:

$$
\begin{aligned}
& A=\delta+\gamma_{1} A_{1}+\gamma_{2} A_{2}+\gamma_{3} A_{3}+\gamma_{4} A_{4}+\varepsilon_{2} \\
& B=\delta+\gamma_{1} B_{1}+\gamma_{2} B_{2}+\gamma_{3} B_{3}+\gamma_{4} B_{4}+\varepsilon_{2}
\end{aligned}
$$

Where:

A, B: Number of children in each respective group

$\mathrm{A}_{1}, \mathrm{~B}_{1}$ : Age

$A_{2}, B_{2}$ : Level of the mother's education

$\mathrm{A}_{3}, \mathrm{~B}_{3}$ : Region

$\mathrm{A}_{4}, \mathrm{~B}_{4}$ : Education

The fourth step, similarly, estimates the behavior of the working sector for the group of the market through a polynomial logit model and uses their coefficients in the estimated equation for the non-market:

$$
\begin{aligned}
& W=\phi+\lambda_{1} W_{1}+\lambda_{2} W_{2}+\lambda_{3} W_{3}+\lambda_{4} W_{4}+\lambda_{5} W_{5}+\varepsilon_{3} \\
& Z=\phi+\lambda_{1} Z_{1}+\lambda_{2} Z_{2}+\lambda_{3} Z_{3}+\lambda_{4} Z_{4}+\lambda_{5} Z_{5}+\varepsilon_{3}
\end{aligned}
$$

Where:

$$
\begin{aligned}
& \mathrm{W}, \mathrm{Z} \text { : Working sector } \\
& \mathrm{W}_{1}, \mathrm{Z}_{1} \text { : Age } \\
& \mathrm{W}_{2}, \mathrm{Z}_{2} \text { : Level of the mother's education } \\
& \mathrm{W}_{3}, \mathrm{Z}_{3} \text { : Years of education } \\
& \mathrm{W}_{4}, \mathrm{Z}_{4}: \text { Composition of the family } \\
& \mathrm{W}_{5}, \mathrm{Z}_{5} \text { : Number of children (Only for the women) }
\end{aligned}
$$

Finally, the model considered the income for the market through the Ordinary Least Squares model. The calculated coefficients will be used to simulate the income of the non market: 


$$
\begin{aligned}
& M=\sigma+\eta_{1} M_{1}+\eta_{2} M_{2}+\eta_{3} M_{3}+\eta_{4} M_{4}+\eta_{5} M_{5}+\varepsilon_{4} \\
& N M=\sigma+\eta_{1} N M_{1}+\eta_{2} N M_{2}+\eta_{3} N M_{3}+\eta_{4} N M_{4}+\eta_{5} N M_{5}+\varepsilon_{4}
\end{aligned}
$$

Where:

M, NM: Represent the income of the market and of the non market, respectively $\mathrm{M}_{1}, \mathrm{NM}_{1}$ : Age

$\mathrm{M}_{2}, \mathrm{NM}_{2}$ : Level of the mother's education

$\mathrm{M}_{3}, \mathrm{NM}_{3}$ : Years of education

$\mathrm{M}_{4}, \mathrm{NM}_{4}$ : Working sector

$\mathrm{M}_{5}, \mathrm{NM}_{5}$ : Region

According to the results found in Figure 8, the estimated distribution for the nonmarket corrected by the coefficients of the market clearly shows progress, with indications of improvement in the perception of incomes when the individuals are close to the market rules.

Figure 8:

\section{Income Behavior in the Non-Market (Observed and Estimated)}

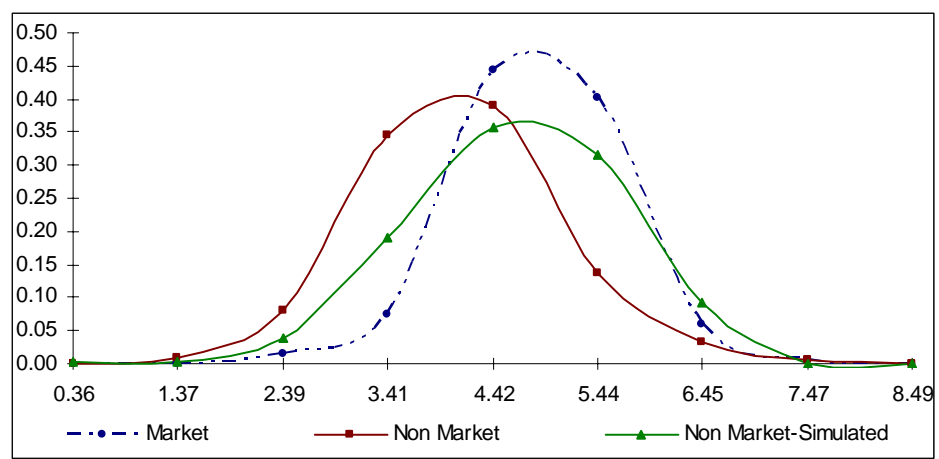

Source: Authors elaboration based on MECOVI 2000

\section{Inequality and social mobility}

As Mercado et.al. (2004) highlights, although the per capita income and the index of income concentration give us the level of well-being of the households in a certain moment, it is important to know the movement of these indicators. It is in that sense that social mobility acquires significance.

A first approach to the concept of social mobility was presented by Berhman (1999) who maintains that this refers to the movements carried out by the economic agents among periods of time relating to their indicators of socio-economic status. Albridge (2001) specifies the concept highlighting that social mobility is not only an indicator tied to temporal movements. It also includes opportunities to move among different social groups, that is, opportunities to enter the labor market, employment securities, development opportunities, and others.

Hassler, Rodríguez Mora and Zeira (2002) develop a model in which social mobility and wage inequality are determined simultaneously and endogenously. In this model, they show that wage inequality has two opposing effects on upward social mobility: the incentive effect and the distance effect. When future wage inequality is expected to be high, this 
provides an incentive for investment in education, which increases upward mobility. However, high wage inequality also reduces the possibility for the poorest segment of the population to invest in education, thus decreasing their upward mobility. This second and opposing effect is called the distance effect.

In this section, we will use the Atkinson coefficient to measure the inequality of income among the different groups that form the labor market in Bolivia. Our objective, as in the previous sections, is to test whether the proximity to an operation based on market rules can increase or diminish the inequality in the income distribution.

As explained in section 4, the Atkinson coefficient uses an aversion coefficient to measure the inequality of income distribution. Whereas the direct measure of this aversion coefficient is not obtainable with the information from our database, we have taken the index of social mobility as a proxy to the aversion coefficient. It is possible to accept that some correlation exists between aversion to inequality and our social mobility index. Indeed, with a higher aversion level to inequality, one would have a higher level of social mobility. A lower aversion level to inequality signifies the society would be willing to accept a lower level of social mobility.

Under that hypothesis, the Decomposition of Fields is presented with the purpose of determining the Social Mobility Index as a proxy to the aversion coefficient in the Atkinson coefficient.

Based on a function of standard income generation, where the logarithm of an individual's income "i" in the period " $\mathrm{t}$ ", it is specified in the following function:

$$
\begin{aligned}
& \ln \left(y_{i t}\right)=\alpha_{t}+\sum_{j=1}^{n} \beta_{j} \omega_{i j t}+\varepsilon_{t} \\
& Y=\sum_{j} a_{j} Z_{j}
\end{aligned}
$$

Where the first term represents the vector of the income logarithms, and $\mathrm{Z}$ is the vector of all the explanatory variables of the sample, that is:

$$
\begin{aligned}
& a=\left(\alpha \beta_{1} \beta_{2} \beta_{3} \ldots \beta_{j} 1\right) \\
& Z=\left(1 x_{1} x_{2} x_{3} \ldots x_{j} \varepsilon\right)
\end{aligned}
$$

We can illustrate the derivation of the Decomposition of Fields better by taking the variance of the logarithm from both sides of the equation of incomes. Carrying out the exercise in the first equation of the log-variance of income, we find the second side can be manipulated in the following way:

$$
\operatorname{Var}\left(Y_{i t}\right)=\operatorname{Cov}\left(\ln Y_{i t}, \ln Y_{i t}\right)=\operatorname{Cov}\left(\sum_{j} a_{i j} Z_{i t j}, \ln Y_{i t}\right)=\sum_{j} \operatorname{Cov}\left(a_{j t} Z_{i j t}, \ln Y_{i t}\right)
$$

Next, we divide the equation by the variance of the logarithm of the income:

$$
\sum_{j} s_{j t}=\frac{\sum_{j} \operatorname{Cov}\left(a_{j t} Z_{i j t}, \ln Y_{i t}\right)}{\operatorname{Var}\left(\ln Y_{i t}\right)}=1
$$

Where the proportion of the variance of the logarithm of incomes is explained by each of the variables, and these are the relative contributions to the factorial inequality. 
The relative contributions are applied to a wide number of measures of inequality, such as the Gini and Theil indices and others.

Following the methodology proposed by Andersen (2003) for the calculation of the Social Mobility Index, we take the relative contributions of greater significance to simulate the degree of aversion to inequality introduced in the Atkinson coefficient. In Table 8 the Fields Decompositions and the Social Mobility Index are presented.

Table 8:

Fields' Decomposition and Social Mobility Index

\begin{tabular}{|l|r|}
\hline Number of observations & 1.067 .00 \\
\hline F( 10, 1056) & 71.85 \\
\hline Prob > F & 0.00 \\
R-squared & 0.40 \\
Adj R-squared & 0.40 \\
Root MSE & 8.00 \\
\hline
\end{tabular}

\begin{tabular}{|l|r|r|r|}
\hline Educational Breach & Coefficients & t-Statistic & F.L.W. \\
\hline Logarithm & $(0.50)$ & $(15.55)$ & 0.16 \\
Years of study & $(0.82)$ & $(12.21)$ & 0.11 \\
Dummy indigenous & 2.74 & 3.85 & 0.02 \\
Years of the mother's study & $(0.24)$ & $(4.17)$ & 0.03 \\
Dummy Family & 3.30 & 4.64 & 0.04 \\
Dummy semi-capitalist & $(2.07)$ & $(2.43)$ & 0.01 \\
Dummy capitalist & $(0.74)$ & $(0.98)$ & 0.00 \\
Dummy urban & $(0.58)$ & $(0.87)$ & $(0.022$ \\
Dummy adolescent woman & 1.77 & 3.36 & 0.00 \\
Adolescent age & 2.25 & 9.69 & $0.02)$ \\
Constant & 7.05 & 3.83 & \\
\hline Summary of F.L.W. & 0.40 & & \\
SMI Index & 0.87 & &
\end{tabular}

Source: Author's elaboration based on MECOVI 2000

Based on Table 8, the Atkinson coefficient was calculated to test the hypothesis that the closer the labor activities are to the logic of the market, the lower inequality of income distribution is observed (Table 9).

Table 9:

Atkinson Coefficient

\begin{tabular}{|l|l|l|l|}
\hline \multicolumn{4}{|c|}{$\begin{array}{c}\text { Atkinson's Coefficient } \\
\mathbf{e}=\mathbf{0 . 8 4}\end{array}$} \\
\hline Total & $\mathbf{0 . 3 3 6}$ & Family & $\mathbf{0 . 3 5 8}$ \\
Women & 0.367 & Women & 0.376 \\
Men & 0.312 & Men & 0.338 \\
\hline Market & $\mathbf{0 . 2 0 7}$ & Semi-Capitalist & $\mathbf{0 . 2 1 7}$ \\
Women & 0.249 & Women & 0.270 \\
Men & 0.189 & Men & 0.198 \\
\hline Non-Market & $\mathbf{0 . 3 4 5}$ & Capitalist & $\mathbf{0 . 2 0 1}$ \\
Women & 0.381 & Women & 0.240 \\
Men & 0.341 & Men & 0.182 \\
\hline
\end{tabular}

Source: Author`s elaboration based on MECOVI 2000 


\section{Conclusions}

The successful experience, in terms of economic growth and the improvement of the population's living conditions, observed in several countries shows us that all reached such achievements thanks to the application of market-oriented policies. This verification, transferred to the structure of Bolivia, led us to investigate whether there exists direct a relationship between the population's living conditions, specifically those related to the distribution of income, and its production organization based on the specificities of the free market concept. Although the results we have obtained in these quantification exercises are not sufficiently robust to conclude definitively that workers who labor in segments closer to the market logic present lower inequality in the income distribution, the results are sufficiently clear to show us that it is a false hypothesis that the more market-oriented the economy is, the higher the inequality of income distribution will be.

It was observed that the differences between the capitalist form and the semicapitalist form of organizing the production were quite clear two decades ago have stumped economics today. This is not for a lack of transition by the semi-capitalist units toward the capitalist form. To the contrary, a greater number of informal activities exist in the capitalist form; or, more precisely, the higher levels of articulation in the capitalist sector are not developed in the same way, that is, under a specified market.

Beyond having found indications sufficiently valid to drive us to support a marketoriented economy as a mechanism to reduce the inequalities in the distribution of income, the social framework observed in Bolivia has generated a hybrid economic structure, tremendously diffuse, that is, different forms of organizing production do not have defined frontiers.

On the other hand, the bibliographical revision done to identify the categories of explanatory behavior for the production factors reflected the necessity to carry out some reductions in the database that certainly impede the application of our conclusions to every aspect of the labor universe.

This limitation exists because the characteristics of the available information do not reflect the complexity of the relationships that characterize our hybrid economic structure. In further research, it will be necessary to carry out a more conceptual study, which permits the better articulation and construction of a categorized household survey that reflects the complexity of this structure. 


\section{References}

Albridge, S. (2001) "Social Mobility: A discussion Paper". Performance and Innovation Unit. London, United Kingdom

Andersen. Lykke E. (2003) "Baja Movilidad Social en Bolivia: Causas y Consecuencias para el Desarrollo” Revista Latinoamericana de Desarrollo Económico. Instituto de Investigaciones Socio-Económicas - Universidad Católica Boliviana. Septiembre.

Berhman Jere R. 1999) "Social Mobility: Concepts and Measurement" The Brookings Institution

Berlin, Isaiah (1958) "Two Concepts of Liberty”. Reproducido en Four Essays on Liberty Oxford, Oxford University Press, 1969.

Bourguignon, Ferreira and Leite (2002). "Beyond Oaxaca-Blinder: Accounting for Differences in Household Income Distributions Across Countries.” Worl Bank Policy Research Paper $\mathrm{N}^{\circ}$ 2828. Washington, DC: The World Bank.

Contreras, Dante (1998). Pobreza, Desigualdad, Bienestar y Políticas Sociales: Elementos Metodológicos para el Debate. Universidad de Chile.

Donoso, Susana (1980) Comercio, Acumulación y Reproducción. Universidad Mayor de San Andrés. Tesis de Licenciatura en Sociología. La Paz, Bolivia.

Fernández, Miguel (1983) La Organización de la Producción y la Distribución en Bolivia. Universidad Católica Boliviana. Tesis de Licenciatura en Economía. La Paz, Bolivia.

Fukuyama, Francis (1996). Confianza. Editorial Atlántida. Buenos Aires.

Findlay, John N. (1969). Reexamen de Hegel. Grijalbo, Barcelona.

Hassler, John J., Rodríguez Mora and Joseph Zeira (2002) "Inequality and Mobility" Institute for international Economic Studies. Stockholm University, January.

Laserna, Roberto (2004). La Democracia en el Ch'enko. Fundación Milenio. La Paz, Bolivia.

Mercado, Alejandro F., Aguilar, Tirza J. (2005) Mercado y Desigualdad Documento de trabajo No. 09/05 Instituto de Investigaciones Socio-Económicas - Universidad Católica Boliviana

Mercado, Alejandro F. (1997). "Una Apostilla a la Racionalidad”. Revista Boliviana sobre Desarrollo Sostenible. Capacidad 21, PNUD. Bolivia, Julio.

Mercado, Alejandro F., Leitón, Jorge, Ríos, Fernando (2004) "Segmentación en el Mercado Matrimonial” Revista Latinoamericana de Desarrollo Económico. Instituto de Investigaciones Socio-Económicas - Universidad Católica Boliviana. Octubre.

Ministerio de Planificación (1979) La organización de la Producción y la Distribución en Bolivia. La Paz, Bolivia

Phelps, Edmund S. (1986). Economía Política. Antoni Bosch, Editor. Barcelona.

Sen, Amartya K. (1988). "The Concept of Development”. Handbook of Development Economics, Amsterdam, North-Holland.

Toranzo, Carlos (1982). Nueva Derecha y Desproletarización en Bolivia. Unitas-ILDIS. La Paz, Bolivia.

Toranzo, Carlos (1993). Lo Pluri-multi o el Reino de la Diversidad. ILDIS. La Paz, Bolivia. 